\title{
The impact of board structure of corporate governance on credit risk: special reference to the banks listed in Colombo Stock Exchange in Sri Lanka
}

\author{
Sameera.T.K.G. \\ Department of Accountancy and Finance, \\ Faculty of Management Studies, Rajarata University of Sri Lanka, Mihintale, Sri Lanka \\ Wijesena:E.P.I.S. \\ Department of Accountancy and Finance, \\ Faculty of Management Studies, Rajarata University of Sri Lanka, Mihintale, Sri Lanka
}

\begin{abstract}
The recent financial crisis and corporate failures at the beginning of the millennium, the emphasis of the business community in corporate governance has shifted towards internal control and risk management issues. As a result, discussion on the impact of corporate governance practices on risk has reached an unprecedented level for academics and practitioners. The rising Non-Performing loans is a threat to any bank since it exposes the bank to many risks. Credit risk is the potential threat to a bank due to a borrower or a counterparty failing to meet its obligations in accordance with the agreed terms. It would expose a bank to many other related risks such as liquidity risk and solvency risk. Accordingly, prudent management of credit risk would ensure the long-term solvency of a bank. Credit risk remained the main risk area of concern to the Sri Lankan banks owing to higher share of loans and advances in the total assets portfolio. Therefore, the purpose of this study is to investigate the impact of board structure on credit risk of banks listed in Colombo Stock Exchange in Sri Lanka. The study was based on the secondary data. Thirteen companies were selected from the listed companies in Colombo Stock Exchange during the period of 2013 to 2017. The Board Size, Board Independence and Meeting Frequency were considered as independent variables, whereas, credit risk as dependent variable. The credit risk was proxied by Non-Performing Loan ratio. The control variables were Financial Leverage and Firm Size. A regression model was used to establish the relationship between board structure and credit risk. The overall results and findings statistically confirmed that the board size and board independence have significantly and negatively impact over the credit risk. Board meeting frequency, firm size and financial leverage have no significant impact on credit risk. Hence, the evidence suggests that the bank increases its board size and majority reperesentation of independent non executive directors in the board are important factors as they help the reduse the credi risk expose by the banks. The participation of independent non-executive members in large proportion improves the independence of the board and increases the capacity of corporate boards to effectively advise, monitor and consequently, reduces the credit risk.
\end{abstract}

Keywords: corporate governance, credit risk, Non-Performing Loan 


\subsection{Introduction}

The global financial crisis was triggered by a series of independent causes such as low interest rates, high leverage, misallocation of investment, unsatisfactory rating practices and insufficient supervision by financial regulators etc. However, it also seems evident that insufficient corporate governance structures played a vital role in the emergence of the financial crisis, which resulted in excessive credit risk taking in banks. Credit risk is the significant risk faced by banks and the success of their business depends on accurate measurement and efficient management of this risk to a greater extent than any other risk. This risk has been attributed to poor governance practices, although very few studies have actually tried to measure the impact of governance on credit risk for both financial and non-financial financial firms. This study attempt to fill this gap and explore the relationship between credit risk and board structure of corporate governance of banks listed in Colombo Stock Exchange in Sri Lanka.

According to the generic definition offered by the Organization for Economic Cooperation and Development, corporate governance involves a set of relationships between corporate management, the board of directors, shareholders and other stakeholders, while also providing the structure through which corporate objectives are set, and the means of accomplishing those objectives and monitoring performance are determined (OECD, 2004). In this light establishing an internal mechanisms to facilitate effective monitoring, corporate governance systems, in terms of both size and composition of the board, has been one of the core themes in all corporate governance initiatives.

Recent history has shown that corporate governance was unable to safeguard against excessive credit risk exposure in a number of financial firms. Kirkpatrick (2009) mentions a specific number of weaknesses such as ineffective information transmission, poor risk management and lack of attention to the warning signs of liquidity risks are leads to crisis conditions in the financial institiutions. Furthermore, it has been argued that board members in a number of financial institutions did not have sufficient competences, since a large proportion of board members lacked financial experience. He further noted weak corporate governance practices which were inadequate for safeguarding extreme taking of risk which resulted in vast sums of nonperforming loans.

Alternatively, high corporate governance focused on shareholder profit maximization will result in a good performance by management, adequate allocation of resources, informed investment strategy, and reliability in reporting. This would exhibit a positive impact on the firm's financial standing and reduce risk in the long run (Warga \& Welsh, 2003). However, when established corporate governance systems are not properly functioning, problems may result. The current business environment is very competitive combined with unstable conditions of the economy, increasing rates of defaulting and commercial and consumer debt hence calls for an enhanced effort to manage and monitor credit risk effectively with a view to ensure 
success and survival of the organization (Altman, 2002). Therefore it is necessary for banks to adopt good corporate governance practices to ensure enhanced credit risk management.

In this regards various studies have been undertaken in relation to corporate governance and risks (Eg. Andrew (2012), Chen, (2003),Hollis, Daniel and Ryan (2004), Truong, Trinhl, Duyen and Nguyen (2015), Seyram, Yakubu and Bawuah (2014)). However there is no study has been undertaken in relation to the effect of corporate governance on credit risk in Sri Lanakan banks. Therefore the present study aimed to address this gap.

\subsection{Problem statement}

Banks are the backbones of a financial system in any country. The healthy growth of the banking system is a pre requisite for economic growth and hence ensuring sustainable profit margins is highly important. Since there is high pressure on the banks to maximize returns to shareholders, they have to continuously scrutinize the operations to ensure that their assets are being efficiently utilized. Due to the recent economic recession and the instances of lapses of financial institutions in both the global and local contexts more stringent regulations have been imposed on the financial institutions. These factors highlight the importance of maintaining the liquidity vs profitability without compromising the depositors' confidence.

The credit risk can be named as a major risk faced by banks since loan portfolio constitutes the major earning asset. The NonPerforming loans would hence demand a high consideration by all banks. However, in consideration of the financials published by Central Bank of Sri Lanka end of year 2017 gross NPL ratio of the country increased to 2.7 percent which is in consistent with the phenomena of majority of Asian countries. State banks in particular are largely affected by this with rising NPLs over the years. A study done by Fonseka (2009) revealed that the higher level of Non-Performing Loans in Bangladesh, Indonesia, Philippines, Malaysia, Thailand and Sri Lanka. Further he stated that Sri Lanka's performance is only better than Bangladesh. As World Bank (2013) explained, Sri Lanka account for moderately high NPL ratio among Asian countries except Bhutan and Pakistan.

The increasing rate of NonPerforming Loans (NPL) is a threat to the stability of any bank since it exposes the banks to many associated risks. Non-Performing Loans (NPL) can be interpreted as bad loans that could be viewed as a function of the borrower's probability of default, and an estimate of the loss experience in the event of default. An advance could fall into the category of NPL due to several reasons such as the bankruptcy, financial difficulties or the death of the borrower. However, a rising NPL ratio would require the immediate attention by the management since it risks the future income of the bank and the funds provided. The risks on NPL ratio is gradually increasing in the banking industry in Sri Lanka indicating the need for further investigation into the reasons which have led to this situation and strengthening the recovery processes of banks. 
Although there are many factors affecting for such condition, the corporate governance is play a vital role of control of such situation by establishing a regulated environment as a result of the risk management process (Knight, 2006). In this regard, corporate governance was defined by Knight (2006) in relation to risk management as an intermediate for governing and controlling an organization with an aim of minimizing the risk. Therefore corporate governance and risk management in any firm are closely related to each other. Failures of banks are particularly costly to a developing country like Sri Lanka and there is a risk of the whole economy being collapsed. Good corporate governance in these banks would, therefore, ensure better performance through credit risk management. In this regards various studies have been undertaken in relation to corporate governance and risks (E.g. Andrew (2012), Chen, (2003),Hollis, Daniel and Ryan (2004), Truong, Trinhl, Duyen and Nguyen (2015), Seyram, Yakubu and Bawuah (2014)). However the review of the studies revealed that no study has been undertaken in relation to the effect of corporate governance on credit risk of listed banks in Sri Lanka. Therefore the present study aimed to address this gap by investigating the effect of corporate governance especially in terms of board practices on credit risk among listed banks in Sri Lanka.

\subsection{Literature review}

Corporate Governance is defined as "a set of relationship between a company's management, its board, its shareholders and other stakeholders. It provides the structure through which the objectives of the company are set, and the means of attaining those objectives and monitoring performance are determined" (OECD Principles of Corporate Governance, 2004). At its most basic level, corporate governance deals with issues that result from the separation of ownership and control. But corporate governance goes beyond simply establishing a clear relationship between shareholders and managers. The importance of good corporate governance ensures that the business environment is fair and transparent and that companies can be held accountable for their actions. Conversely, weak corporate governance leads to waste, mismanagement, and corruption. (Youssef ,2009).

Credit risk is defined as the probability that some of a bank's assets, especially its loans, will decline in value and possibly become worthless. Because banks hold little owners' capital relative to the aggregate value of their assets, only a small percentage of total loans need to go bad to push a bank to the brink of failure. Thus, management of credit risk is very important and central to the health of a bank and indeed the entire financial system. As banks make loans, they need to make provisions for loan losses in their books. The higher this provision becomes, relative to the size of total loans, the riskier a bank becomes. An increase in the value of the provision for loan losses relative to total loans is an indication that the bank's assets are becoming more difficult to collect. The goal of credit risk management is to maximize a bank's risk-adjusted rate of return by maintaining credit risk exposure within acceptable parameters. Banks need to manage 
the credit risk inherent in the entire portfolio as well as the risk in individual credits or transactions. The effective management of credit risk is a critical component of a comprehensive approach to risk management and essential to the long-term success of any banking organization.

The Non-Performing Loans (NPL) represents credits which the banks perceive as possible loss of funds due to customers failure to repay the monthly installments. They are further classified into substandard and doubtful bank credit category hinders bank from achieving their set targets. Proper risk management is essential for the survival of a bank, and it enables management to allocate resources to risk units based on a tradeoff between risk and return potential (Charles ,2013).

Truong, Trinh, Duyen and Nguyen (2015) examined the Impact of Corporate Governance on Financial Risk in Vietnamese Commercial Banks. They approached the corporate governance mechanism with an aim of studying the impact of corporate governance dynamics on capital risk, credit risk, as well as liquidity risk. The approach divides corporate governance separately into the internal mechanism and external mechanism. The empirical study indicated that board strengths, information disclosure, foreign capital, and stakeholder roles have a significant impact on financial risk management in the banking systems.

Andres and Vallelado (2008) argue that a large board size should be preferred to a small size because of the possibility of specialization for more effective monitoring and advising functions. However, Lipton and Lorsch (1992); and Yermack (1996) have proffered counter argument that the benefit of specialization which Andres and Vallelado (2008) emphasize may be swallowed by the incremental cost of poorer communication and decision-making associated with larger groups. Donaldson and Davis (1994) suggest that 'managers are good stewards of the corporation and conscientiously work to attain high levels of corporate profit and shareholder returns. The theory affirms that the main role of the board of directors is to advise and support management rather than to discipline and monitor, a view which runs counter to the agency theory. Switzer and Wang (2013) examine the impact of corporate governance variables on bank credit risk. After controlling for firm-specific characteristics, the study provides evidence that commercial banks with larger boards and older CFOs are associated with significantly lower credit risk levels.

Hollis, Daniel and Ryan (2004) investigated the effects of Corporate Governance on Firms' Credit Ratings. The study proved that CEOs of firms that have speculative grade credit ratings are overcompensated with higher marks than those in firms with investment grade ratings. Besides that, this overcompensation exceeds the CEO's share of additional debt costs related to lower credit scores.

Seyram, Yakubu and Bawuah (2014) examined the corporate governance and risk management in the banking sector of Ghana. The study indicated that board of directors, senior staff are actively involved in risk management and the most important types of 
risk facing the sampled banks were operating risk, interest rate risk, credit risk, solvency risk, and liquidity risk. However, it was also noted that not all employees are angaged in risk management. Nyakoe (2012), investigated the relationship between corporate governance and risk management practices among commercial banks in Kenya. The study concludes that there is a significant influence of corporate governance on risk management practices of commercial banks in Kenya.

The study of Kodithuwakku (2014), investigated the impact of credit risk management on performance of Commercial Banks in Sri Lanka. Return on Assets was used as dependent variable and Non-Performing Loans to Total Loans was used as indicator of credit risk. The study revealed that the main task of having a credit risk management is to reduce the financial losses and thereby it improves the profitability of the banks. According to the Jensen (1993) a significant percentage of external directors serving on the board contribute to a strong reduction of banking risk. Similarly Ben Khediri (2006) investigated that boards with a significant proportion of external directors, risk coverage probability is high. Frequency of board meetings is considered to be an important way of improving the effectiveness of the board (Conger and Lawler ,2009) A study conducted by Francis et al. (2012) indicated that firms with poor board attendance at meetings perform significantly worse than boards which has good attendance during financial crisis. Accordingly, the main hypotheses derived to be tested in this study are as follows:
$\mathrm{H}_{1}$ : There is a negative relationship between board size and credit risk.

$\mathrm{H}_{2}$ : There is a negative relationship between board independence and credit risk.

$\mathrm{H}_{3}$ : There is a negative relationship between board meeting frequency and credit risk.

\subsection{Methodology}

The population of the study is banking and insurance companies listed in the CSE of Sri Lanka. All the banks other than the insurance companies were selected as sample of the study based on the structure of the company. The main business activity of the banks is earning interest and providing loans to the customers which is differ to the main business activity of the insurance companies. Therefore insurance companies were not selected as the sample. Thirteen (13) listed bank were selected. In order to meet the objectives of the study, data were collected from secondary sources mainly from the audited financial statements included in the annual reports of the selected companies, which were published by the CSE. Specifically, the financial statements of the sampled firms were collected for the period of five years ending with 2017. Both inferential statistical and descriptive techniques were used to analyze the data. According to Healey (2011), descriptive statistics enables the researcher to condense large quantities of data using methods that are understandable to the observer. Descriptive analyses were used to analyze the extent of corporate governance practices and level credit risk expose by the banks. Both linear regression and correlation analyses were utilized to assess the hypothesized relationships 
between the independent and dependent variables.

Table 1. Operationalization of Variables

\begin{tabular}{|c|c|}
\hline \multicolumn{2}{|l|}{ Dependent Variable } \\
\hline Credit Risk & $\begin{array}{l}\text { Non- } \\
\text { Performing } \\
\text { Loan / Total } \\
\text { Loans }\end{array}$ \\
\hline Independent Variables & \\
\hline Board Size & $\begin{array}{l}\text { The number of } \\
\text { directors of the } \\
\text { board }\end{array}$ \\
\hline Board & Number of \\
\hline Independence & $\begin{array}{l}\text { Independent } \\
\text { Directors/ } \\
\text { Number of } \\
\text { Total Directors }\end{array}$ \\
\hline $\begin{array}{l}\text { Board } \\
\text { Meeting } \\
\text { Frequency }\end{array}$ & $\begin{array}{l}\text { The number of } \\
\text { meeting held } \\
\text { per year }\end{array}$ \\
\hline Control variables & \\
\hline $\begin{array}{l}\text { Financial } \\
\text { Leverage } \\
\text { Firm Size }\end{array}$ & $\begin{array}{l}\text { Total Liability/ } \\
\text { Total Assets } \\
\text { log size of the } \\
\text { Assets }\end{array}$ \\
\hline
\end{tabular}

The impact of board structure on bank's credit risk was estimated by using following regression equation.

$\mathrm{NPL}=\alpha+\beta_{1} \mathrm{BS}+\beta_{2} \mathrm{BI}+\beta_{3} \mathrm{MF}+\beta_{4} \mathrm{FS}+\beta_{5} \mathrm{FL}+\varepsilon$

Where;

NPL $=$ Non Performing Loans, BS $=$ Size of the board, $\mathrm{BI}=$ Board Independence, $\mathrm{MF}=$ Board meeting frequency, FS = Firm Size, FL = Financial Leverage, $\beta 0 \beta 1 \beta 2 \beta 3 \beta 4$ and $\beta 5$ are the beta equation coefficients, $\varepsilon$ : Standard Error term.

\subsection{Results and discussion}

Table 2 shows the descriptive statistics of independent and dependent variables. The mean value of Non-Performing Loan 5.1257 and minimum and maximum value were 0.90 and 21.36 respectively. However this is above the international standard of 2 per cent, yet as a developing economy this is suggestive of effective and efficient loan monitoring and collection systems in the banking sector in Sri Lanka. The mean value of board size was 10.35 and minimum and maximum value of the board size of the banks were 5 and 16 members respectively. The average board size is in line with international standard. In addition, the result of table 2 indicates that the mean value of the Board Independence was 0.4760 and minimum and maximum were 0.33 and 0.75 respectively. Board Meeting Frequency presented the mean value of 14.68 and minimum and maximum values were 10 and 28. Further mean value of the firm's size was 25.3056, minimum and maximum value 23.02 and 27.50. The mean value of Financial Leverage was 0.8624 and minimum and maximum values were 0.01 and 1.21 respectively.

Table 2. Descriptive Statistics

\begin{tabular}{|lllll|}
\hline & $\begin{array}{l}\text { Mini } \\
\text { mum }\end{array}$ & $\begin{array}{l}\text { Maxi } \\
\text { mum }\end{array}$ & Mean & $\begin{array}{l}\text { Std. } \\
\text { Deviation }\end{array}$ \\
\hline NP & 0.9 & 21.36 & 5.1257 & 3.70204 \\
L & & & & \\
BS & 5 & 16 & 10.35 & 2.521 \\
BI & 0.33 & 0.75 & 0.476 & 0.10815 \\
M & 10 & 28 & 14.68 & 3.514 \\
F & 10 & & & \\
FS & 23.02 & 27.5 & 25.3056 & 1.2365 \\
FL & 0.01 & 1.21 & 0.8624 & 0.1443 \\
\hline
\end{tabular}


NPL- Non Performing Loan, BS- Board Size, BIBoard Independence, MF- Meeting Frequency, FSFirm Size, FL- Firm Leverage.

Table 3 presents the result of correlation analysis. According to the results non-performing loan ratio represented negative strong correlation with board size (-0.679) and also non-performing loan ratio represented the negative moderate relationship with the board independent (-0.447) and firm size (-0.219). In addition to that table represents non-performing loan ratio positively correlated with board meeting frequency (0.029) and Financial Leverage (0.073).

Table 3: Correlations Analysis

\begin{tabular}{|llllll|}
\hline & NPL & BS & BI & MF & FS \\
\hline BS & $-0.679^{* *}$ & & & & \\
BI & $-0.447^{* *}$ & $0.379^{* *}$ & & & \\
MF & 0.029 & -0.008 & -0.026 & & \\
FS & -0.219 & 0.181 & $.416^{* *}$ & -0.176 & \\
FL & 0.073 & -0.186 & -0.147 & -0.218 & 0.132 \\
\hline
\end{tabular}

NPL- Non Performing Loan, BS- Board Size, BIBoard Independence, MF- Meeting Frequency, FSFirm Size, FL- Firm Leverage.

\begin{tabular}{|lcccc|}
\hline \multicolumn{5}{c}{ Unstandardized } \\
\multicolumn{5}{|c|}{ Coefficients } \\
& B & t & Sig. \\
& & Error & & \\
\hline (Constant) & 20.012 & 7.779 & 2.573 & 0.013 \\
BS & -0.889 & 0.147 & -6.066 & 0.000 \\
BI & -7.733 & 3.704 & -2.088 & 0.041 \\
MF & 0.001 & 0.1 & 0.015 & 0.988 \\
FS & -0.017 & 0.311 & -0.054 & 0.957 \\
FL & -1.848 & 2.5 & -0.739 & 0.463 \\
\hline Adj. R Square $=0.576$ & F $=51.668$ & Sig F $=0.000$ \\
\hline
\end{tabular}

Table 4 reproduces the result of regression analysis. Adj. R Square and F -test reveal the fact that regression model is well fitted to the data. The predictive power of the model Adj. R Square is $57.6 \%$. It means that the explanatory variables in our model explain $57.6 \%$ variation in the dependent variable. The significance of the F-statistic reported in Table 4 implies that the explanatory variables jointly and significantly explain the variations in the dependent variable. Evidence in Table 4 shows that board size is negatively related to credit risk of the bank. This is statistically significant. Thus Hypothesis 1 is well supported. It presumes that as a bank increases its board size, it is likely to reduce its credit risk. This finding downfalls the small board theory which argues that smaller boards are more effective than their larger counterparts (Lipton and Lorsch, 1992; and Yermack, 1996) and supports the theory of Andres and Vallelado (2008) and Klein (2002) who argue that a large board size should be preferred to a small size because of the possibility of specialization for more effective monitoring and advising functions. Table 4 shows that board independence has a negative relationship with credit risk, implying that as the number of independent directors on the board of a bank increases, there is a corresponding decreases in the credit risk of the bank. Hypothesis H1, thus, supported. This result is consistent to the findings of a study conducted by Donaldson and Davis (1994). Board meeting frequency, firm size and financial leverage have no significant effect on the credit risk of banks, because their $\mathrm{p}$ values are more than 0.05 .

Table 4 Regression Analysis

NPL- Non Performing Loan, BS- Board Size, BIBoard Independence, MF- Meeting Frequency, FSFirm Size, FL- Firm Leverage. 


\subsection{Conclusion}

This research analyzed the impact of board structure on credit risk in the banks listed in Colombo Stock Exchange during 2013 to 2017. According to the results of the study, there is negative relationship between board size, board independence, firm size and credit risk. Thus Hypothesis 1 and 2 are well supported. That indicates if the board size increases, risk of the company is decreasing. Board size increase mean that various type of members can be participated in the decision making process. This results support the resource dependency theory, suggesting that large board could provide valuable expertise, access to resources, high quality advice and is harder for insiders to control, which could help to lower banks' credit risk levels. Further, Board independence was negatively related with the bank credit risk and it implies that independent boards confer higher survival probabilities to banks. Board meeting frequency and firm leverage were positively affected for the credit risk. Therefore these results suggested that the maintaining of good board structure may be improving the performance of the company and it may be help to reduce the credit risk. One major policy implication is in the terms of governance of listed banks that having a large board size consisting of people with relevant experience and expertise is likely to augur well for credit risk management. Therefore, recommend that, subject to their scope of operations, should consider increasing the size of their boards with competent directors if they would like to reduce their credit risk.

\section{References}

Altman, E.I. (2002). Managing credit risk: A challenge for the new millennium. Economic Notes, 31, 201-214 \& Finance $29,1813-1834$.

Andrew, J. (2012). The relationship between corporate governance and insolvency risk among commercial banks in Liberia. Wiley, Chichester. Journal of Governance, 83(5), 1258-1264.

Andres, P. D. and Vallelado, E. (2008), Corporate Governance in Banking: The Role of the Board of Directors, Journal of Banking \& Finance, 32, 2570-2580

Charles, O. K. (2013). "Impact of Credit Risk Management and Capital Adequacy on the Financial Performance of Commercial Banks in Nigeria". Journal of Emerging Issues in Economics, Finance and Banking, An Online International Monthly Journal, Arab Infortech FZLLC

Chen, H.J. (2003). The Relationship between Corporate Governance and Risk-Taking. The Review of Financial Studies, Vol.7 No:1, 1994, 125-148.

Conger, J., \& Lawler, E. E. (2009). "Sharing leadership on corporate boards: A critical requirement for teamwork at the top".

Donaldson, L. and J.H. Davis (1994), Boards and Company Performance: Research Challenges the Conventional Wisdom, Corporate Governance: An International Review, 2(3), 151-160.

Fonseka, N. (2009). "Bouncing back - the opportunities and constraints". Paper Presented at 20th Anniversary Convention of Association of Professional Bankers in Sri Lanka. 
Francis, J., Huang, A., Rajgopal, S., \& Zang, A. (2008). "CEO reputation and earnings quality". Contemporary Accounting Research, Vol 25 (1): 109-147.

Francis, J., Huang, A., Rajgopal, S., \& Zang, A. (2012). "CEO reputation and earnings quality". Contemporary Accounting Research, Vol 25 (1): 109-147.

Hollis, A.S., Daniel W. C., \& Ryan L., (2004). Effects of Corporate Governance on Firms' Credit Ratings. International Journal of Economics and Finance, 3(2), 176-185.

Jensen, M. (1993). "The Modern Industrial Revolution, Exit, and the Failure of Internal Control Systems". Journal of Finance, Vol. 48, No. 3, 831-857.

Klein, A. (2002), Audit Committee, Board of Director Characteristics, and Earnings Management," Journal of Accounting and Economics 33(3), 375-400.

Kirkpatrick, G. (2009). The Corporate Governance Lessons from the Financial Crises, OECD 2009/1.

Knight, K.W. (2006). Risk management a journey, not a destination. Paper presented at the Executive Meeting 2006. Hotel Do Frade \& Golf Resort, Angra Dos Reis, Brazil. 20th May 2006.

Kodithuwakku, S. (2014). Impact of Credit Risk Management on the Performance of Commercial Banks in Sri Lanaka.

Lipton, M. \& Lorsch, J. (1992), A Modest Proposal for Improved Corporate Governance Business Lawyer, 48, 59-77.

Nyakoe, J. K. (2012). The relationship between corporate governance and risk management practices among commercial banks in Kenya. Unpublished MBA

Project, University of Nairobi.

OECD (Organization for Economic Cooperation and Development), 2004. Principles of corporate Governance. Retrieved from

http://www.oecd.org/corporate/ca/corpora tegovernanceprinciples.

Seyram P.K., Yakubu A.S. \& Bawuah B. (2014). Corporate governance and risk management in the banking sector of Ghana. International Journal of Information Management, 22, 405-419.

Switzer, L.N. \& Wang, J. (2013), Default Risk Estimation, Bank Credit Risk and Corporate Governance, Financial Markets, Institutions and Instruments, 91122.

Truong, H., Trinh, T., Duyen, T. \& Nguyen, T.T. (2015). Impact of Corporate Governance on Financial Risk in Vietnamese Commercial Banks. Journal of Financial Regulation and Compliance, December, 15(2): 205-224.

Warga, A. \& Welch, I. (1993). Bondholder Losses in Leveraged Buyouts, Review of Financial Studies, 6, 959 - 982

World Bank. (2013). "World development indicators". $\quad$ Retrieved from http://databank.worldbank.org/data/downl oad/WDI-2013-ebook.pdf

Yermack, D. (1996), Higher Market Valuation of Companies with a Small Board of Directors, Journal of Financial Economics, 40, 185-211.

Youssef, M. T. (2009). Corporate Governance: An Overview - Around the Globe. 